\title{
Bathymetric measurements of Morskie Oko Lake
}

\author{
Adam Choiński ${ }^{{ }^{*}}$, Agnieszka Strzelczak ${ }^{2}$ \\ ${ }^{1}$ Institute of Physical Geography and Environmental Planning, Adam Mickiewicz University, Dzięgielowa 27, 61-680 Poznań, Poland, \\ e-mail: choinski@amu.edu.pl, * - corresponding author \\ ${ }^{2}$ Faculty of Food Sciences and Fisheries, West Pomeranian University of Technology in Szczecin, Pawła VI 3, 71-459 Szczecin, Poland, \\ e-mail: Agnieszka-Strzelczak@zut.edu.pl
}

\begin{abstract}
The aim of this study was to gather and summarize bathymetric measurements of Morskie Oko Lake which have been carried out up to now. Apart from the two existing plans from 1909 and 1934, a plan presenting the arrangement of isobaths in 1879 was worked out on the basis of numerical data. Moreover, after field investigation with an echo sounder in 2011, a new bathymetric plan was created. All four plans were used to calculate the basic morphometric parameters of Morskie Oko. Bathygraphic curves were determined from the volume of water found by measuring the areas between consecutive isobaths. The least accurate data come from 1879 while there is a considerable resemblance between the plans dated to 1934 and 2011. In case of the most recent plan, the measurements were for the first time related to the average, multi-annual (1963-2010) water level. Thus, the greatest depth found in 2011 can be regarded as the maximum depth. Further bathymetric studies could help to determine the rate of shallowing of Morskie Oko lake caused by weathered rock material, transported for instance by avalanches.
\end{abstract}

Key words: Morskie Oko Lake, bathymetric measurements

\section{Introduction}

Morphometric parameters for lakes are of great importance. They contribute to the explanation of many research issues, such as water balance, rate of water exchange or rate of shallowing. Bathymetric measurements of lakes located in the Tatra Mountains started over 200 years ago. The ground-breaking studies were performed by Staszic (1815), who investigated the vicinity of Morskie Oko in 1805. It should be underlined that in those years the name "Morskie Oko" was used for the present-day "Czarny Staw pod Rysami" while the present-day "Morskie Oko" was called "Jezioro Rybie". Some researchers (for example Borowiak 2000) have not noticed that fact, which has contributed to misunderstandings and inaccuracies. The historical outline of bathymetric measurements is intriguing, because the aforementioned Staszic did not have a boat and tried to measure the lake depth standing at the shore. He was simply repeatedly throwing a lead ball, which reached its maximum distance at the level of 583 feet. Following the Paris foot, equal to $28.78 \mathrm{~cm}$, the determined depth reached $168 \mathrm{~m}$.
The first morphometric study of Morskie Oko, comparable with contemporary investigation, was performed by Dziewulski (1879). However, that plan did not contain any isobaths but only measuring sites and the bottom profiles along measuring lines. Its scale was 1:5000. Another researcher of Morskie Oko Lake was Sawicki (1929), who worked out the lake plan at the scale of 1:2000. In 1934, within the work of the Military Geographical Institute, a more up-to-date plan was prepared by Śliwerski (1935). After 76 years, a contemporary bathymetric plan was worked out by Choiński and Strzelczak (2011).

\section{Methods}

From the historical point of view, only two bathymetric plans were worked out for Morskie Oko Lake, one dated to 1909 and another to 1934. For the sake of comparative analysis of the lake plans, the numerical data of Dziewulski (1879) were transformed into isobaths. As a result, four plans were obtained, dated to $1879,1909,1934$ and a newly worked out plan based on the study performed in 2011 . 
All the field investigations were carried out from vessels. In the case of the first three studies, they were performed using a weighted rope while the latest one in 2011 with the Garmin echo sounder. In order to assess the comparability of isobaths, they were presented every $10 \mathrm{~m}$. As a result, the lake area, average depth, maximum depth and water volume were estimated. As for the water volume, it was calculated as the sum of partial water volume between consecutive isobaths while the average depth was the ratio between the total volume and lake area. The partial water volumes were used to determine the bathygraphic curves. As for the plan from 2011, the measurements were related to the average, multi-annual (1963-2010) water level.

\section{Study area}

The catchment area of Morskie Oko Lake (together with Czarny Staw), measured to the outflow of Rybi Potok, covers $5.9 \mathrm{~km}^{2}$. Water bodies constitute over 55 ha, i.e. $9.3 \%$. The catchment area is surrounded by the highest peaks of the Polish part of the Tatra Mountains and their elevation related to the Morskie Oko Lake surface exceeds $1000 \mathrm{~m}$. As a result of the considerable slopes of the mountainsides as well as of the low retention capacity of weathered rocks, the reaction of the lake to precipitation is very quick. The catchment area in its lowest part is closed by a moraine step, at which Stanisław Staszic's mountain shelter is located. Rocks constitute $40 \%$ of the area, morainic cover $20 \%$ and meadows $40 \%$. The unique character of Morskie Oko and also Czarny Staw is manifested by the exceptional water transparency, which is the consequence of their location. The transparency of Czarny Staw measured with a Secchi disc on September 15, 1999 (Kurzyca et al., 2000) reached $23.0 \mathrm{~m}$ (the greatest measured in Poland). In Morskie Oko the transparency was at the level of $15 \mathrm{~m}$. That situation was caused by the fact that the catchment area of Morskie Oko is much larger and, as a result, it receives larger loads of suspensions.

Morskie Oko and its vicinity are located in the area of the highest level of precipitation in Poland. The sum of the average annual precipitation usually exceeds $1600 \mathrm{~mm}$. Between May and October it is above $1000 \mathrm{~mm}$. The contribution of solid precipitation (i.e. snow, hail) is over $24 \%$. The mean annual specific runoff is close to $50 \mathrm{l} \mathrm{s}^{-1} \mathrm{~km}^{-2}$, which corresponds to the annual runoff layer at the level of $1500 \mathrm{~mm}$, which is the highest in Poland. The denudation runoff index exceeds $100 \mathrm{t} \mathrm{km}^{-2}$ and it is also the maximum value for Poland.

\section{Results}

Results of the calculations are presented in Table 1 and Figures 1-4. It is clearly visible that the oldest study deviates considerably from the other measurements. For example, the maximum depth found in 1879 was the lowest and reached $49.5 \mathrm{~m}$. This situation undeniably results from the sparse number of sampling sites, i.e. only 29 . In the case of lake area, data obtained by Dziewulski (1879) differ by over 10\% from the other investigations, which are generally quite similar (differences between them do not exceed 0.75 ha). The highest value of maximum depth, at the level of $53.8 \mathrm{~m}$, was found by Sawicki (1909). The results of this study are also characterized by the largest range of the $50 \mathrm{~m}$ isobath (5.4 ha, Fig. 2). Such a great depth was probably recorded due to an unusually high water level during measurements. However, no information was given on that issue. The maximum depth of 51.8 $\mathrm{m}$ can be regarded as the most reliable from all the studies. The monitoring of the water level in Morskie Oko started in 1963. The average, multi-annual value for the years $1963-2010$ amounts to $108 \mathrm{~cm}$. The maximum depth of $51.8 \mathrm{~m}$ was determined considering the water level during the field investigation (September

Table 1. Comparison of morphometric data for Morskie Oko lake

\begin{tabular}{|l|c|c|c|c|}
\hline \multicolumn{1}{|c|}{$\begin{array}{c}\text { Author } \\
\text { Parameter }\end{array}$} & $\begin{array}{c}\text { Dziewulski } \\
(1879)\end{array}$ & $\begin{array}{c}\text { Sawicki } \\
(1909)\end{array}$ & $\begin{array}{c}\text { Śliwerski } \\
(1934)\end{array}$ & $\begin{array}{c}\text { Choiński \& Strzelczak } \\
(2011)\end{array}$ \\
\hline Area [ha] & 29.93 & 33.90 & 34.18 & 33.39 \\
Maximum depth [m] & 49.5 & 53.8 & 50.8 & 51.8 \\
Average depth [m] & 28.1 & 29.2 & 28.5 & 29.7 \\
Water volume [dam ${ }^{3}$ ] & 8419.5 & 9884.6 & 9752.2 & 9904.3 \\
Altitude [m a.s.I.] & $1393.0^{1}$ & - & 1392.8 & 1394.6 \\
\hline
\end{tabular}

${ }^{1}$ After Lencewicz (1925) 

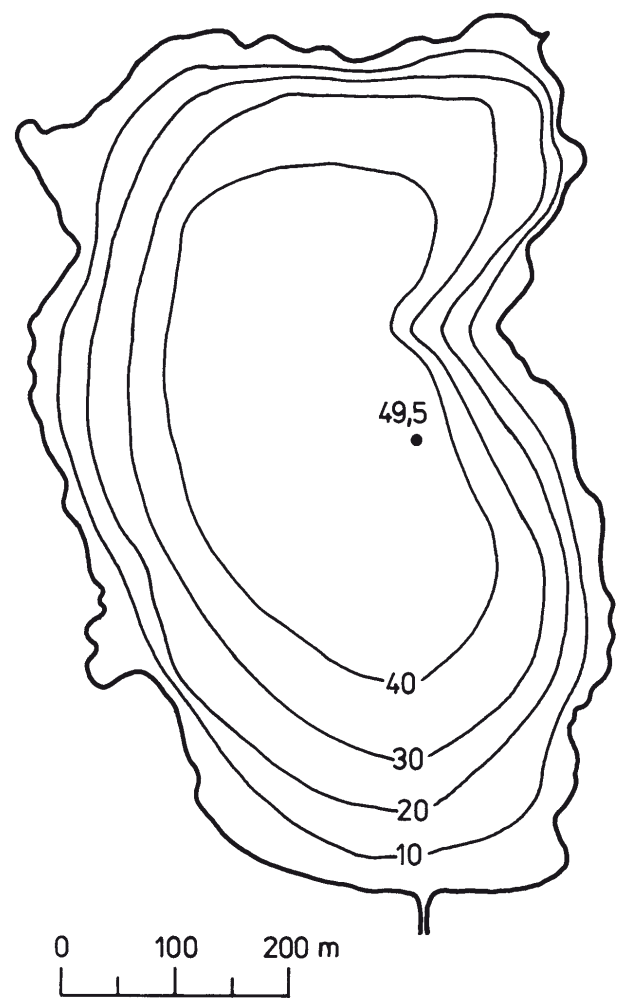

Fig. 1. Bathymetric plan 1879

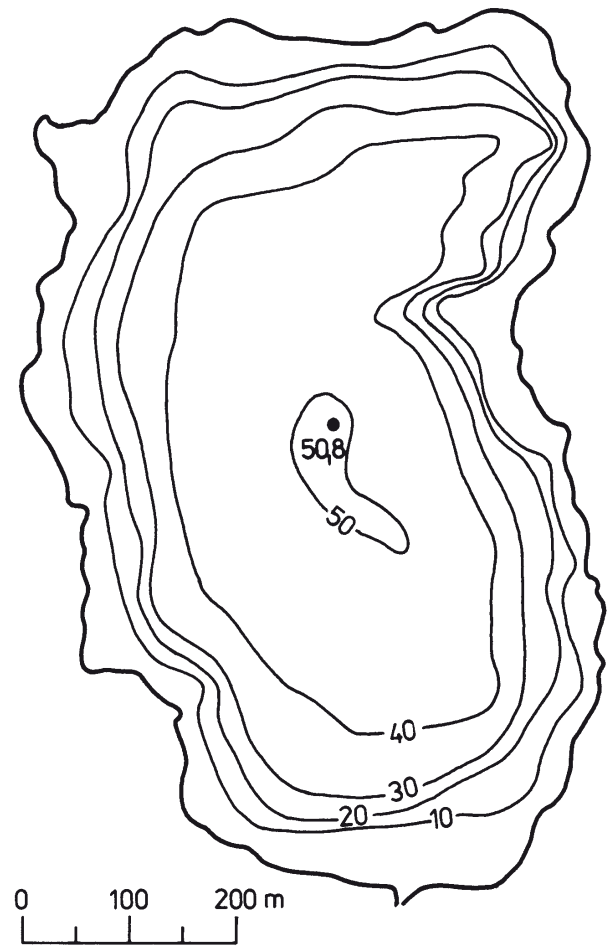

Fig. 3. Bathymetric plan 1934

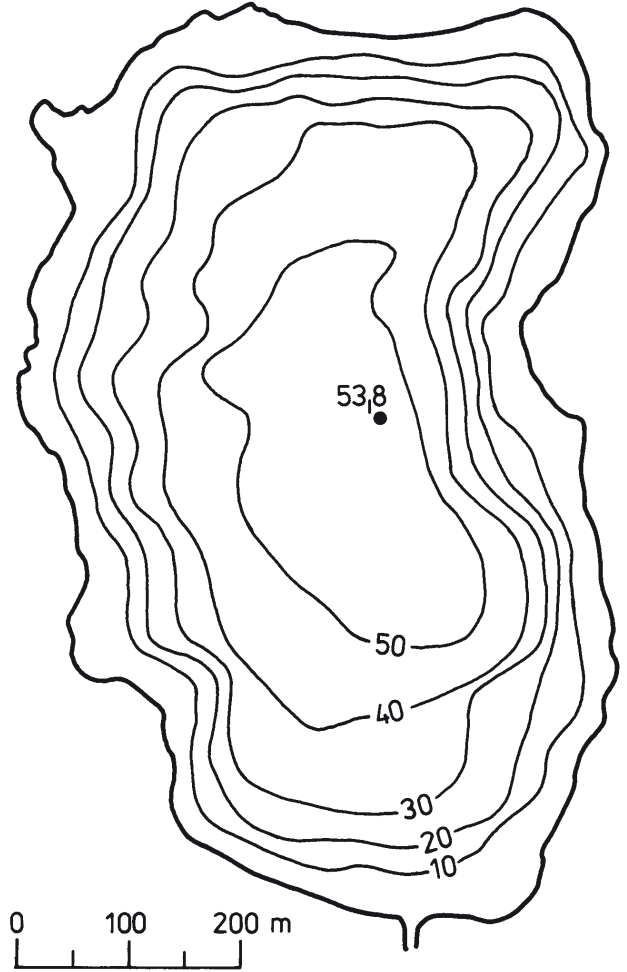

Fig. 2. Bathymetric plan 1909

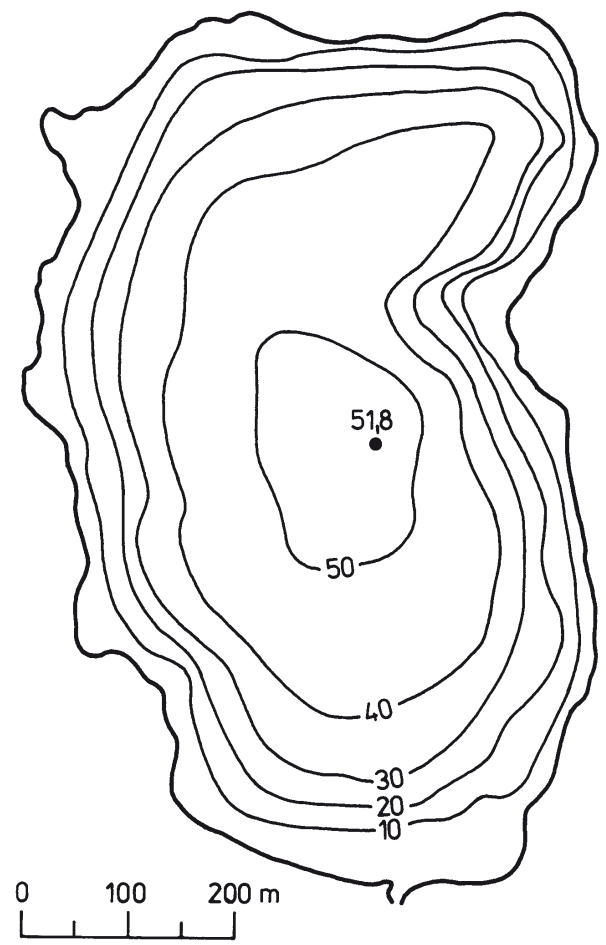

Fig. 4. Bathymetric plan 2011 
$7,8,2011$ ), which was $94 \mathrm{~cm}$ for hydrometric zero located at $1393.67 \mathrm{~m}$ a.s.l. It should be underlined that this depth is in accordance with the results obtained on August 8, 1999 - also 51.8 m (Choiński 2000). The range of average depth is not wide and varies between 28.1 and $29.7 \mathrm{~m}$. In turn, considerable difference was obtained in terms of water volume between the study from $1879\left(8419.5 \mathrm{dam}^{3}\right)$ and the other investigations, which gave similar values of this parameter. It unquestionably results from the lack of the $50 \mathrm{~m}$ isobath (Fig. 1). Water volume determined from the remaining studies varies between $9752.2 \mathrm{dam}^{3}$ and $9904.3 \mathrm{dam}^{3}$, although the distributions of isobaths are clearly different. It is particularly visible for the $50 \mathrm{~m}$ isobath, which covers 5.4 ha, 0.6 ha and 2.6 ha, respectively to the chronology of measurements. However, detailed analysis of the distribution of other isobaths shows that it varies depending on the number of measuring sites and, as a consequence, the final results are averaged.

The bathygraphic curves are shown in Fig. 5. The one reflecting the situation in 1879 differs considerably from the others. The intermediate course is characterized by the curve obtained for measurements conducted in 1909, while the curves for 1934 and 2011 display high resemblance. In the case of those two studies the precision of measurements as well as the density of measuring sites were quite similar, so any differences probably result from different water levels.

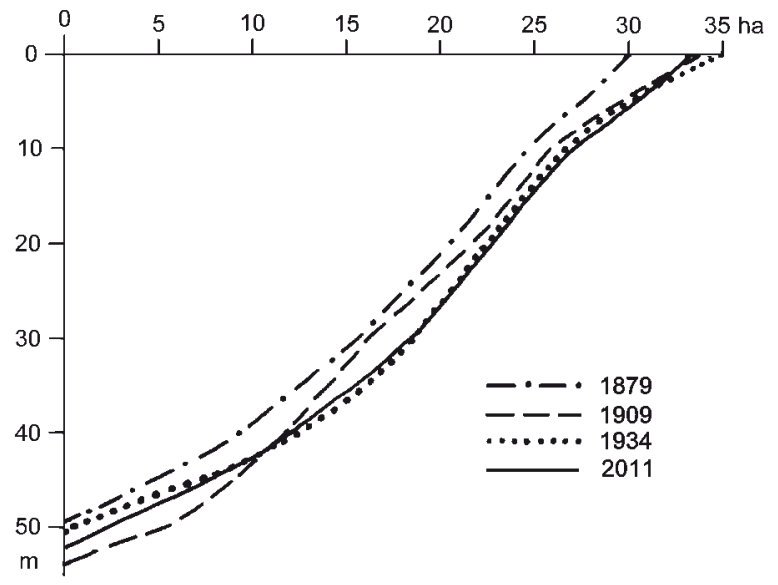

Fig. 5. Comparison of bathygraphic curves

\section{Discussion}

Morskie Oko Lake, due to extremely oligotrophic waters, differs considerably from other lakes located in the lake areas of northern Poland. In its case no intensive deposition of organic sediments or expansion of riparian vegetation are observed. However, the lake is still liable to shallowing. Avalanches plunging downslope carry to the lake basin various clastic material, from boulders to fine fractions. Moreover, fine weathered material is carried out by water courses and surface runoff after torrential rain or a thaw. A large part of the lake bottom is covered with stone rubble, which causes fluctuations in echo sounder readings. Therefore, repeating precise echo sounder measurements, for instance every 10 years, is well justified. It could indicate the rate of shallowing and the decrease in water resources. Such comparisons are possible only when referred to a stable point of reference, i.e. hydrometric zero. The water gauge station installed several decades ago at the outflow of the Rybi Potok stream from Morskie Oko gives such an opportunity. The depth measurements carried out with an echo sounder in 2011 were for the first time referred to the average, multi-annual water level. This is particularly important for drawing up bathymetric plans, because the multi-annual fluctuations of water level exceed $110 \mathrm{~cm}$. Therefore, both lake area and water volume greatly depend on the water level at which the survey is conducted.

Another issue is the maximum depth. Following the procedure of referring depth measurements to the average, multi-annual water level allows us to assume the depth of $51.8 \mathrm{~m}$ as maximal. However, a reservation should be made that it is possible to find a local overdeepening between boulders covering the bottom.

\section{Conclusions}

This study is a comparison of four bathymetric plans of Morskie Oko Lake dated to 1879, 1909, 1934 and 2011. These plans were used to calculate morphometric parameters and to determine bathygraphic curves. The variability of the morphometric data obtained does not unambiguously indicate the evolution of the lake in terms of shallowing. This situation is probably caused by the different time of measurements. The water level of Morskie Oko changes considerably, i.e. multi-annual fluctuations exceed $1.1 \mathrm{~m}$. 
The bathymetric plan based on measurements carried out with an echo sounder in 2011 can be regarded as the most reliable since the depths were referred to the average mutli-annual water level. Thus, the assumption that the depth of $51.8 \mathrm{~m}$ is maximal is justified. Further bathymetric studies of Morskie Oko seem to be purposeful. They would allow us to determine the rate of shallowing caused by weathered rock material transported by surface runoff, water courses and avalanches.

\section{Acknowledgments}

We want to express our gratitude to Paweł Skawiński, PhD Eng., the Director of the Tatra National Park, for the permit for scientific research in the area of Morskie Oko. We would also like to thank Alicja Baczyńska, MSc and Mariusz Ptak, PhD for their help in preparing this manuscript.

\section{References}

Borowiak D., 2000, Uzupełniające pomiary batymetryczne jezior tatrzańskich (Supplementary bathymetric measurements of the Tatra lakes) [in:] Czochański T., Borowiak D. (eds.), Z badań geograficznych w Tatrach Polskich (From the geographical investigations in the Polish Tatra Mountains), Wyd. UG, Gdańsk: 81-96 (in Polish, English summary).

Choiński A., 2000, Najgłębsze jeziora Tatr polskich w świetle najnowszych pomiarów głębokościowych (The deepest lakes of the Polish Tatra Mountains in light of recent bathymetric measurements), Czas. Geogr. 71(1): 99-103 (in Polish, English summary).

Dziewulski E., 1879, Rybie jezioro w Tatrach polskich (Lake Rybie Jezioro in the Polish Tatra Mountains), Pam. Tow. Tatrz. 4: 114-123 (in Polish).

Kurzyca I., Choiński A., Kaniecki A., Siepak J., 2009, Water ecosystems affected by human impact within the protected area of the Tatra National Park (Poland), Oceanol. Hydrobiol. Stud. 38(3): 77-86.

Lencewicz S., 1925, Badania jeziorne w Polsce (Investigations of lakes in Poland), Prz. Geogr. 4: 1-70 (in Polish, French summary).

Sawicki L., 1929, Atlas jezior tatrzańskich (Atlas of lakes of the Tatra Mountains), Pr. Kom. Geogr. PAU 2, Kraków.

Staszic S., 1815, O ziemiorodztwie Karpatow i innych gor i rownin Polski (Carpathian and other Polish mountains' and plains' geology), Reprint (1955), Wyd. Geol., Warszawa, p. 390.

Śliwerski K., 1935, Pomiar batymetryczny jezior w Tatrach (Bathymetric measurements of lakes in the Tatra Mountains), Wiad. Służby Geogr. 9(3-4): 295-310 (in Polish, French summary). 